\title{
AN ANALYSIS OF RESEARCH TRENDS ON EARLY CHILDHOOD ARTS EDUCATION FOR ARTS CONVERGENCE EDUCATION
}

\section{LEE KYOUNG HYE \& KIM SUK JA IS CORRESPONDING AUTHOR}

Early Childhood Education, Korea National University of Education, South Korea

The purpose of this study was analysis of research trends on early childhood arts education for practice of arts convergence education. And the objects of this study were 65 journal articles related to early childhood arts education in KCI( Korea Citation Index). The 65 journal articles were selected the through the KERIS (Korea Education and Research Information Service).The results of this study were as follows. First, the types of research were analyzed as qualitative research(21\%), quantitative research(40\%), and literature review(39\%).Second, the research subjects were analyzed as young child (19\%), teacher for early childhood(29\%), parent of young child (0\%), and literature(52\%). Third, the research years were analyzed as 2005 2008(19\%), 2009 2012(32\%), 2013 2016(49\%).Fourth, the research areas were analyzed as one field of arts(5\%), arts and arts(37\%), arts and sciences(12\%), arts and mathematics(3\%), arts and meditation(1\%), arts and languages(1\%), aesthetics education(19\%), cultural arts(13\%), art convergence(1\%), and arts teachers(8\%).Lastly, the research themes were analyzed as cultural arts education(13\%), aesthetic inquiry(19\%), effects of art education(21\%), awareness, needs and actual situation about art education(10\%), integration of arts(18\%), development of arts programs(9\%), arts teachers(7\%) and research trends of art education(4\%).The results of this study suggest the feasibility of arts convergence education in various fields of early childhood education. This is because the results of this study show the aspect of arts integration and arts convergence in various fields of knowledge and life such as arts and arts, integration of arts and science, mathematics, meditation, languages, aesthetics education, cultural arts and arts teachers.
\end{abstract}

KEYWORDS: Arts Convergence Education, Early Childhood Arts Education \& Aesthetics Education

Received: Feb 16, 2017; Accepted: Apr 06, 2017; Published: Apr 10, 2017; Paper Id.: IJESRAPR201716

\section{INTRODUCTION}

\section{Background}

Art leads us to the beauty world. The trip to the beauty world makes us happy. Because the trip to the beauty world presents us something new, and this gift touches us. 'Early childhood arts education' is music, art, dance, drama, and literature education.

Young children feel beauty through experience in various art areas such as music, art, dance, drama, and literature. And these artistic experiences help children to self- understand and communicate with the surrounding world around them. In other words, art develops creativity, problem solving, critical thinking, communication, self-initiative and cooperative skills. Therefore, participation in these arts activities can improve spontaneity and self-expression, and create creative outcomes. (David A. Sousa, \& Tom Pilecki, 2014).Classical music, in particular, has the power to purify the mind and clear the mind. Just as green forests and clear air cleanse our bodies and minds, music is a precious gift that cleanses our bodies and minds like clear air (Geumnansae, 2016). I believe in the power of painting. Painting relieves stress and makes my mind comfortable. The paintings enable 
communication, healing and change me (Kim seon hyun, 2015). Picture book is a good art education material. Early childhood literature education and early childhood arts education using picture books also promote children's understanding of themselves and others and their understanding of the world. Children who like to move enjoy themselves expressing their emotions, thoughts and feelings through their bodies.

Art convergence refers to the integration of art and art, art and life, art and learning. In other words, art convergence is to connect various fields of art such as music, art, dance, and literature to life and to discover and create something new in such process and result. Arts convergence education refers to a series of processes that look understanding of the children and the world around them through the mirror of art and discover beauty and create something new in art. And also, the arts convergence education can be said the integrated education centered on arts subject education such as music, art, drama and other subject such as science, mathematics, social in these arts subject education(Kim Jeung Hee, \& Chong Hyun Ju, 2013). 'Finding the beauties’,

'Expressing artistically', and 'Appreciating the art' are categories of contents of the art experience area presented in the Nuri-Curriculum (Korean Early Childhood Education Course) description book. And these artistic experience such as 'Finding the beauties', 'Expressing artistically', and 'Appreciating the art' should be integrated through the encounter with various art media in daily life of young children(The Ministry of Education, Science and Technology, 2013). In other words, arts convergence education is to appreciate art works of various genres such as music, art, dance, and literature. And arts convergence education is expressing their thoughts and feelings in various art activities such as talking, singing, dancing, expressing the body, drawing, making, and playing in the drama. The content and method of convergence are open without limitation. In other words, we seek and utilize art integration and art convergence in various ways in various fields such as convergence of thinking, convergence of knowledge, and convergence of activity methods. Accordingly these perspectives support the rationale and necessity of arts convergence education in early childhood education. Therefore, the purpose of this study is to explore the possibility and direction for practicing of arts convergence education in early childhood education by examining trends in research related to early childhood art education.

\section{METHODS}

The purpose of this study was analysis of research trends on early childhood arts education for practice of arts convergence education. And the objects of this study were 65 journal articles related to early childhood arts education in KCI (Korea Citation Index). The 65 journal articles were selected the through the KERIS (Korea Education and Research Information Service). The process of selection of journal articles for early childhood arts education is as follows. First, as a result of inputting the keyword 'early childhood arts education', a total of 408journal articles were searched(Search on October 18, 2016).A total of 115 papers were extracted from 408 journal articles, excluding the papers not related to early childhood arts education, after reviewing the contents of the articles through titles and abstracts of the articles. Among the 115 journal articles, 67 journal articles were finally selected as objects of this study. These 67 journal articles are listed in $\mathrm{KCI}$, and correspond to the analysis year of this study, included contents related to early childhood arts education such as arts education, arts activities, cultural arts, aesthetics education.

The 65 journal articles were analyzed according to the types of research, research subjects, research years, research areas and research themes. The specific analysis tools was as follows. Firstly, the types of research contain qualitative research, quantitative research and literature review. Secondly, the research subjects contain young child, teacher for early childhood, parent of early childhood and literature. Thirdly, the research years were divided by 4 
yearsas2005 2008, 2009 2012, 2013 2016. Fourthly, the research areas include one field of arts, arts and arts, arts and science, arts and mathematics, arts and meditation, arts and languages, aesthetics education, cultural arts, art convergence, and arts teachers. Lastly, the research themes include cultural arts education, aesthetic inquiry, effects of art education, awareness, needs and actual situation about art education, integration of arts, development of arts programs, arts teachers and research trends of art education. In addition, the frequency of repetition was indicated when there was a duplication of contents corresponding to each item of the analysis tool in one study article. And this analysis tool made by Kyoung-hye Lee based on books related to art, music, convergence education, art convergence education, research method, and previous research related to research trends on early childhood arts education, early childhood education. These procedures to make the analysis tool for research of journal articles related to early childhood arts education and to check validity of contents in analysis compliance about research trends on early childhood arts education were accomplished with 3 professors of early childhood education.

Excel program was used for data analysis to perform frequency and percentage

The analysis tool for research trends on early childhood arts education was as follows

Table 1. The example of repetition frequency indication in analysis tool item was as

Follows Table 2.

Table 1: Contents of Analysis Tool for Research Trends on Early Childhood Arts Education for Arts Convergence Education

\begin{tabular}{|c|c|c|c|c|c|}
\hline \multicolumn{6}{|c|}{$\begin{array}{c}\text { Contents Of Analysis Tool For Research Trends On Early Childhood } \\
\text { Arts Education }\end{array}$} \\
\hline $\begin{array}{l}\text { Content } \\
\text { categories }\end{array}$ & \multicolumn{5}{|c|}{ Details item of content } \\
\hline $\begin{array}{l}\text { Types of } \\
\text { research }\end{array}$ & $\begin{array}{l}\text { Qualitative } \\
\text { research }\end{array}$ & $\begin{array}{c}\text { Quantitative } \\
\text { research }\end{array}$ & \multicolumn{3}{|c|}{ Literature review } \\
\hline $\begin{array}{l}\text { Research } \\
\text { subjects }\end{array}$ & Young child & $\begin{array}{l}\text { Teacher for early } \\
\text { childhood }\end{array}$ & \multicolumn{2}{|c|}{ Parent of young child } & Literature \\
\hline $\begin{array}{l}\text { Research } \\
\text { years }\end{array}$ & 2005 2008 & 2009 2012 & \multicolumn{3}{|l|}{ 2013 2016 } \\
\hline \multirow{2}{*}{$\begin{array}{l}\text { Research } \\
\text { areas }\end{array}$} & $\begin{array}{l}\text { One field of } \\
\text { arts }\end{array}$ & Arts and arts & Arts and science & $\begin{array}{l}\text { Arts and } \\
\text { mathematics }\end{array}$ & Arts and meditation \\
\hline & $\begin{array}{l}\text { Arts and } \\
\text { languages }\end{array}$ & $\begin{array}{l}\text { Aesthetics } \\
\text { education }\end{array}$ & Cultural arts & $\begin{array}{l}\text { Art } \\
\text { convergence }\end{array}$ & Arts teachers \\
\hline \multirow{2}{*}{$\begin{array}{l}\text { Research } \\
\text { themes }\end{array}$} & $\begin{array}{l}\text { Cultural arts } \\
\text { education }\end{array}$ & Aesthetic inquiry & \multicolumn{2}{|c|}{ Effects of art education } & $\begin{array}{l}\text { Awareness, needs and } \\
\text { actual situation about art } \\
\text { education }\end{array}$ \\
\hline & $\begin{array}{l}\text { Integration of } \\
\text { arts }\end{array}$ & $\begin{array}{l}\text { Development of } \\
\text { arts programs }\end{array}$ & \multicolumn{2}{|l|}{ Arts teachers } & $\begin{array}{l}\text { Research trends of art } \\
\text { education }\end{array}$ \\
\hline
\end{tabular}

Table 2: The Example of Repetition Frequency Indication in Analysis Tool Item

\begin{tabular}{|l|l|c|}
\hline \multicolumn{1}{|c|}{ Title of Article } & \multicolumn{1}{|c|}{$\begin{array}{c}\text { An Analysis on the Early Childhood Education } \\
\text { Teacher's Recognition and Utilization of Arts-Science } \\
\text { Integrated Program }\end{array}$} \\
\hline \multicolumn{1}{|c|}{ Author } & \multicolumn{1}{|c|}{ Kim Nam Yun \& Kim Myoung Jung } \\
\hline Content Categories & \multicolumn{1}{|c|}{ Details Item of Content } & Frequency \\
\hline Types of research & Quantitative research & 1 \\
\hline Research subjects & Teacher for early childhood & 1 \\
\hline Research years & $2013 \sim 2016$ & 1 \\
\hline
\end{tabular}




\begin{tabular}{|l|l|c|}
\hline \multicolumn{2}{|c|}{ Table 2: Contd., } \\
\hline Research areas & Arts and science & 1 \\
\hline \multirow{3}{*}{ Research themes } & $\begin{array}{l}\text { Awareness, needs and actual situation about } \\
\text { art education }\end{array}$ & 1 \\
\cline { 2 - 3 } & Integration of arts & 1 \\
\hline
\end{tabular}

\section{RESULTS}

\section{The Distribution according to Research Types of Articles Related to Early Childhood arts Education}

The results of this study were as follows. First, the types of research were analyzed as qualitative research (21\%), quantitative research(40\%), and literature review(39\%). The results of this study show that qualitative research has been performed less than quantitative research and literature review. The results suggest that the qualitative research on early childhood arts education should be expanded. Qualitative research is the study of phenomena occurring spontaneously without the need for experimental manipulation in the context of the study (Hwang ha ek, 2010). Therefore qualitative research related to early childhood arts education provides more detail on practice of more natural early childhood arts education in field of early childhood education. Table 3 shows the results of the analysis of articles related to early childhood arts education according to types of research.

\section{Table 3: The Distribution According to Research Types of Articles Related to Early Childhood Arts Education Frequency (\%)}

\begin{tabular}{|l|c|}
\hline \multicolumn{2}{|c|}{ The distribution of Articles According to Types of Research } \\
\hline Qualitative research & $17(21 \%)$ \\
\hline Quantitative research & $32(40 \%)$ \\
\hline Literature review & $31(39 \%)$ \\
\hline Total & $\mathbf{8 0}(\mathbf{1 0 0 \%})$ \\
\hline
\end{tabular}

The distribution according to research subjects of articles related to early childhood arts education

Second, the research subjects were analyzed as young child(19\%), teacher for early childhood(29\%), parent of young child $(0 \%)$, and literature $(52 \%)$. The results of this study show that research related to young child has been performed less than research related to teacher for early childhood and literature. The results call for the expansion of research on arts education related to young child. Young children also want a happy life. Parents and teachers should try to help young children to be happy and to keep young children happy. Parents and teachers should also encourage young children to discover and appreciate a variety of sources of happiness, including nature (Hong Yong Hee, \& Na Young I et. al, 2013). From this point of view, art experience is also a key element of the young children's happiness. Therefore, it is necessary to increase the research on young children such as children's happiness and early childhood arts education. In addition, the results of this study call for the implementation of research related to parental art education for young children. This is because the home artistic environment and the role of parents are very important elements of early childhood arts education. Therefore, it is necessary to carry out studies on the awareness, needs of parent related to arts education for young children, actual condition of early childhood arts education in home. Furthermore, it is considered that the development study of various arts play programs with parents is also required. Table 4 shows the results of the analysis of articles related to early childhood arts education according to research subjects. 
Table 4: The Distribution According to Research Subjects of Articles Related to Early Childhood Arts Education Frequency (\%)

\begin{tabular}{|l|c|}
\hline \multicolumn{2}{|c|}{ The Distribution According to Research Subjects of Articles } \\
\hline Young child & $29(19 \%)$ \\
\hline Teacher for early childhood & $45(29 \%)$ \\
\hline Parent of young child & $0(0 \%)$ \\
\hline Literature Total & $79(52 \%)$ \\
\hline \multicolumn{1}{|c|}{ T3(100\%) } \\
\hline
\end{tabular}

The distribution according to research years of articles related to early childhood arts education

Third, the research years were analyzed as 2005 2008(19\%), 2009 2012(32\%), 2013 2016(49\%). The results of this study show a large increase in the number of studies related to early childhood arts education. This is an encouraging result for the field practice of early childhood arts education. This is because the increase in the number of study cases related to early childhood arts education can be interpreted as an increase of interest in early childhood arts education. In addition, the results of this study are consistent with the findings of a journal article (Lee, Songmi, Kim, Min-jin, 2016) that since 2000, integrated art activities and child science education was increasing yearly based on research. Table 5 shows the results of the analysis of articles related to early childhood arts education according to research years.

\section{Table 5: The Distribution According to Research Years of Articles Related to Early Childhood Arts Education Frequency (\%)}

\begin{tabular}{|c|c|}
\hline \multicolumn{2}{|c|}{ The Distribution According to Research Years of Articles } \\
\hline $2005 \sim 2008$ & $11(19 \%)$ \\
\hline $2009 \sim 2012$ & $16(32 \%)$ \\
\hline $2013 \sim 2016$ & $17(49 \%)$ \\
\hline Total & $\mathbf{6 5}(\mathbf{1 0 0 \% )}$ \\
\hline
\end{tabular}

The distribution according to research areas of articles related to early childhood arts education

Fourth, the research areas were analyzed as one field of arts(5\%), arts and arts(37\%), arts and science(12\%), arts and mathematics(3\%), arts and meditation(1\%), arts and languages(1\%), aesthetics education(19\%), cultural arts(13\%), art convergence( $1 \%)$, and arts teachers(8\%). The results of this study show that the research areas of early childhood arts education varied, and there were relatively many researches on the integration of art and arts, aesthetics education, culture arts, arts and science. And the results of this study suggest the feasibility of arts convergence education in various fields of early childhood education. This is because the results of this study show the aspect of arts integration and arts convergence in various fields of knowledge and life such as arts and arts, integration of arts and science, mathematics, meditation, languages, aesthetics education, cultural arts and arts teachers. Table 6 shows the results of the analysis of articles related to early childhood arts education according to research areas.

Table 6: The Distribution According to Research Areas of Articles Related to Early Childhood Arts Education frequency (\%)

\begin{tabular}{|l|c|}
\hline \multicolumn{2}{|c|}{ The Distribution According to Research Areas of Articles } \\
\hline One field of arts & $4(5 \%)$ \\
\hline Arts and arts & $29(37 \%)$ \\
\hline Arts and science & $9(12 \%)$ \\
\hline Arts and mathematics & $2(3 \%)$ \\
\hline Arts and meditation & $1(1 \%)$ \\
\hline Arts and languages & $1(1 \%)$ \\
\hline Aesthetics education & $15(19 \%)$ \\
\hline
\end{tabular}




\begin{tabular}{|l|c|}
\hline \multicolumn{2}{|c|}{ Table 6: Contd., } \\
\hline Cultural arts & $10(13 \%)$ \\
\hline Art convergence & $1(1 \%)$ \\
\hline Arts teachers & $6(8 \%)$ \\
\hline Total & $\mathbf{7 8 ( 1 0 0 \% )}$ \\
\hline
\end{tabular}

The distribution according to research themes of articles related to early childhood arts education

Lastly, the research themes were analyzed as cultural arts education (13\%), aesthetic inquiry (19\%), effects of art education(21\%), awareness, needs and actual situation about art education(10\%), integration of arts(18\%), development of arts programs $(8 \%)$, arts teachers $(7 \%)$ and research trends of art education(4\%). The results of this study show that the subject of research on early childhood arts education is diverse. Especially, there were many studies on the effects of art education, aesthetic inquiry, integration of arts, and cultural arts education. And this results suggest the viability of early childhood arts education on variety of theme such as art education activities, aesthetic inquiry, integration of arts, and cultural arts education. The heart of aesthetics is pleasure, spontaneity and creativity. Beauty is the artistic outcome of such voluntary play. In the process of exploring aesthetics by participating in aesthetic lessons, young children maximize their artistic impulses such as dancing, writing letters, drawing and appreciating (Im Bu Yeon, 2015). In other words, through esthetic lessons, young children will experience art convergence activities. In this regard, results of this study suggest that arts convergence education can be utilized in a variety of artistic activities such as aesthetic inquiry, integration of arts, cultural arts education, etc. Table 7 shows the results of the analysis of articles related to early childhood arts education according to research themes.

\section{Table 7: The Distribution According to Research Themes of Articles Related to Early Childhood Arts Education Frequency (\%)}

\begin{tabular}{|l|c|}
\hline \multicolumn{2}{|l|}{ The Distribution According to Research Themes of Articles } \\
\hline Cultural arts education & $11(13 \%)$ \\
\hline Aesthetic inquiry & $16(19 \%)$ \\
\hline Effects of art education & $17(21 \%)$ \\
\hline $\begin{array}{l}\text { Awareness, needs and actual } \\
\text { situation about art education }\end{array}$ & $8(10 \%)$ \\
\hline Integration of arts & $15(18 \%)$ \\
\hline Development of arts programs & $7(8 \%)$ \\
\hline Arts teachers & $6(7 \%)$ \\
\hline Research trends of art education & $3(7 \%)$ \\
\hline \multicolumn{2}{|c|}{ Total } \\
\hline
\end{tabular}

As mentioned above, the research trends of arts education for children for arts convergence education were examined. In general, many research methods related to early childhood arts education were conducted quantitative researches and literature researches. The research subjects were much more researches related to teachers for early childhood and literature than children and parents. Also, the number of articles related to early childhood arts education increased significantly with years. The research areas of early childhood arts education varied, and there were relatively many researches on the integration of art and arts, aesthetics education, culture arts, arts and science. The subjects of research on early childhood arts education articles varied. Especially, there were many studies on the effects of art education, aesthetic inquiry, integration of arts, and cultural arts education. 


\section{CONCLUSIONS}

The proposal for the follow - up study is as follows. First, qualitative research on early childhood arts education and practice of research targeting young child and parents are required. Next, we need to research the integration of arts and arts, the integration of arts and other subjects, and how to integrate arts on life of the children. Furthermore, it is necessary to study the development and practical practice of the arts convergence education program. This is because arts convergence education is to present the mirrors of beauty to individual young child by connecting the life of young child to arts.

\section{REFERENCES}

1. David A. Sousa \& Tom Pilecki (2014). Theory and practice of STEAM Education - rom STEM to STEAM. Dabinchibooks.

2. Geumnansae (2016). Classic travel of Geumnansae. Artbook

3. Hong Yong Hee, \&Na Young I, \& Jang Hyun Jin, \& Kim Hye Jeon, \& Jeon U Young(2013). Exploring Happy Education for Young Children. Changjisa.

4. Hwang ha ek, (2010). Child research method. Jeongminsa.

5. Im Bu Yeon, (2015). Nuri Curriculum, Meet aesthetics. Yangseown.

6. Kim Nam-Yun, \& Kim MyoungJung. (2013) An analysis on the early childhood education teacher's recognition and utilization of arts-science integrated program. Jangan University, \& Baekseok Arts University. Journal of Early Childhood Education. 17, No. 3, 107-130

7. Kim Jeung Hee, \& Chong Hyun Ju. (2013). A study on Practice of, art centered STEAM

8. Education. Gyeongin National University. Journal of art education, 35, 245-266

9. Kim Seon Hyun(2015). The power of painting. Eight Point.

10. Lee Song Mi, \& Kim Min Jin. (2016). A study on research trends of early childhood science education integrated art-activity. Chung-ang University.

11. The Ministry of Education, Science and Technology. (2013). 3 5 Nuri-Curriculum description book by age. Seoul: The Ministry of Education, Science and Technology $\cdot$ Ministry of Health. 
